Brazilian Journal of Microbiology (2009) 40: 446-449

ISSN 1517-8382

\title{
ISOLATION OF RABIES VIRUS FROM THE PAROTID SALIVARY GLANDS OF FOXES (Pseudalopex vetulus) FROM PARAÍBA STATE, NORTHEASTERN BRAZIL
}

\author{
Maria Luana Cristiny Rodrigues Silva ${ }^{1}$, Fabiano da Silva Lima ${ }^{1}$, Albério Antônio de Barros Gomes ${ }^{{ }^{*}}$, Sérgio Santos de \\ Azevedo $^{1}$, Clebert José Alves ${ }^{1}$, Fernanda Bernardi ${ }^{2}$, Fumio Honma Ito $^{3}$ \\ ${ }^{1}$ Unidade Acadêmica de Medicina Veterinária, Centro de Saúde e Tecnologia Rural, Universidade Federal de Campina \\ Grande, Patos, PB, Brasil; ${ }^{2}$ Centro de Vigilância Sanitária e Controle de Zoonoses “Tereza Rodrigues de Camargo”, Ibiúna, \\ SP, Brasil; ${ }^{3}$ Departamento de Medicina Veterinária Preventiva e Saúde Animal, Faculdade de Medicina Veterinária e \\ Zootecnia, Universidade de São Paulo, São Paulo, SP, Brasil
}

Submitted: July 21, 2008; Returned to authors for corrections: August 22, 2008; Approved: May 03, 2009.

\begin{abstract}
To determine the presence of rabies virus in the parotid salivary glands, 12 road-killed rabies-positive hoary foxes (Pseudoalopex vetulus) were tested by using the fluorescent antibody test (FAT) and mouse inoculation test (MIT). All 12 parotid salivary glands were positive for both tests, although in some cases several passages were required. The findings of this study support the importance of the hoary fox as rabies reservoir in the semi-arid region of Paraíba State, Northeastern Brazil.
\end{abstract}

Key-words: Parotid gland, fox, rabies virus, isolation, Paraíba State

Rabies is primarily transmitted by the inoculation of the virus within the saliva through the bite of an infected animal. The most important reservoirs for human rabies in Latin America is the dog and wild animals as foxes, and bats are also responsible for transmission to human and animals (1). In northern Colombia, rabies viruses were isolated from foxes (Urocyon cinereoargenteus), $\operatorname{dogs}$ and humans and all belonged to a single genetic variant, when G-L intergenic region and protein $\mathrm{G}$ and a fragment of $\mathrm{L}$ protein were compared (17).

The hoary fox (Pseudalopex vetulus) is widely distributed in Brazil, especially in the northeastern region where it is common to raise foxes and other wild animals as pets, although this practice is considered a felony by the IBAMA (Brazilian Institute for Environment and Natural Resources). This close relationship between man and wild animals raises the risk of rabies transmission to human and domestic animals (13).

*Corresponding Author. Mailing address: Universidade Federal de Campina Grande, Av. Universitária, Bairro Santa Cecília, 58700-970, Caixa Postal 64, Patos, Paraíba, Brasil.; Tel. +55 833423 3397; fax: +55 833423 4659.; E-mail: alberiogomes@bol.com.br 
There are reported cases of rabid foxes and human transmission in the states of Ceará (3), Paraíba (13), Pernambuco, Bahia and Minas Gerais (2). During the period of August 15th 2000 to February 11th 2003, 24 humans were attacked by hoary foxes in the semi-arid region of Paraíba and medicated in Patos Municipality (19).

The antigenic characterization with monoclonal antibodies and the partial genetic sequencing of the $\mathrm{P}$ gene of rabies virus samples isolated from Brazilian domestic and wild canids showed two rabies groups related to the hoary fox (P. vetulus), which straighten the importance of this species as a rabies virus reservoir in the semi-arid region of the state of Paraíba (7).

The aim of this work was to isolate rabies virus from the parotid salivary glands of the hoary foxes ( $P$. vetulus) of the semi-arid region of Paraíba State, Northeastern Brazil, which had been diagnosed positive for rabies by means of the fluorescent antibody (FAT) and mouse inoculation test (MIT) of brain materials.

Materials of the salivary glands taken from the hoary foxes of the semi-arid region of the state of Paraíba were provided by the Virology Laboratory of the Veterinary Medicine Academic Unit, Health Center and Rural Technology, Federal University of Campina Grande (UAMV/CSTR/UFCG), and IBAMA's license number 3322001-CGEF to make research on the Brazilian wild canids. A total of 12 road-killed out of 287 examined had been diagnosed positive for rabies through the FAT and MIT applied for brain specimens.

Twelve parotid salivary glands from these animals were selected and individually macerated and diluted to make a $20 \%$ suspension with a solution of sterilized distilled water containing $2 \%(\mathrm{v} / \mathrm{v})$ rabbit sera, penicillin $(500 \mathrm{IU} / \mathrm{mL})$ and streptomycin (1,560 IU/mL). After centrifuging at 2,000 rpm for 10 minutes, a volume of $0.03 \mathrm{~mL}$ was inoculated intracerebrally in groups of ten mice, according to Koprowski (15). Mice were daily observed for 21 days for rabies symptoms. After this period, brain from mice groups which did not show rabies signs were collected and re inoculated using the same procedure. Mice that died prior to the end of the 21 days were confirmed by FAT applied to their brain tissues.

Mice used for diagnostic and virus isolation procedures were 21 day-old Swiss albino, lineage CH3 Rockfeller, weighing from 11 to 15 grams, and maintained at the UAMV/CSTR/UFCG facilities.

The fluorescent antibody test was made according to Goldwasser and Kissling (12) and modified by Dean et al. (10).

All 12 parotid salivary glands were positive for both FAT and MIT, although two of them required two mouse passages and the other needed three additional passages, as shown in Table 1 .

Matouch et al. (16) inoculated fourteen foxes intramuscularly with 50 or $5,000 \mathrm{LD}_{50}$ of rabies virus in red foxes (Vulpes vulpes), and demonstrated the presence of rabies virus in the saliva of 12 animals and in the salivary glands of 13 ones. Carey and Lean (6) reported that the viral titer found in salivary gland $\left(10^{-4.2}\right)$ was similar to that obtained for brain $\left(10^{-4.5}\right)$, but titers in other animals were varied, $10^{-3.0}$ and $10^{-4.6}$, respectively for salivary gland and brain. Secord et al. (18) showed that virus was in parotid salivary gland of $43(97.7 \%)$ of 44 foxes. Beauregard and Casey (4) detected rabies antigen in salivary glands of 23 foxes through FAT and MIT and our results corroborate the results of the previous works.

Rabies virus was detected in salivary glands of skunks (Mephitis mephitis) and titers were higher for submandibular and lower for zygomatic, molar, and sublingual glands, while for nasal mucosa the viral titers 
varied from low to moderate, and occasionally they were similar to those found for brain samples (4).

Delpietro et al. (11) isolated rabies virus from $4.6 \%$ of salivary glands (submaxillary and parotid) and 1\% of saliva of 87 naturally infected bovines.

From the rabid hoary foxes, it is possible to isolate rabies virus from the parotid salivary glands, although in some situation it might be necessary to perform more than one brain passage in mouse. These results may be explained by the freezing condition submitted to preserve the biological specimens, which culminated with a very low viral titer, necessitating the blind passages in mice for viral isolation.
Carnieli $\mathrm{Jr}$ et al. (7) in the analyzes of the molecular epidemiology of rabies virus isolated from wild canids in Northeastern Brazil, indicated two distinct rabies cycles among canids in Brazil, one represented by wild canids and the other domestic canids. Carnieli Jr et al. (8) reported that foxes (Cerdocyon thous and Pseudalopex vetulus) are frequently associated with rabies. Kobayashi et al. (14) performed the phylogenetic chararacterization of rabies virus from carnivores in Brazil, and they found in the state of Paraíba, two sublineages of fox rabies viruses.

These findings support the importance of the hoary fox as rabies reservoir in the semi-arid region of Paraíba State, Northeastern Brazil.

Table 1. Results of the fluorescent antibody test (FAT) and mouse inoculation test (MIT) in brain tissue of mice inoculated with suspensions of parotid salivary glands of the road-killed hoary foxes positive for rabies, Paraíba State, Brazil

\begin{tabular}{ccccc}
\hline $\begin{array}{c}\text { Hoary Fox } \\
\text { Samples }\end{array}$ & FAT & \multicolumn{3}{c}{ MIT } \\
\cline { 2 - 5 } & & $\mathbf{1}^{\text {st }}$ Passage & $\mathbf{2}^{\text {nd }}$ Passage & $\mathbf{3}^{\text {rd }}$ Passage \\
\hline 1 & + & + & --- & --- \\
3 & + & + & --- & + \\
4 & + & - & - & --- \\
5 & + & + & --- & --- \\
6 & + & - & + & -- \\
7 & + & + & --- & --- \\
8 & + & + & --- & --- \\
9 & + & + & + & --- \\
10 & + & - & --- & -- \\
11 & + & + & -- & \\
12 & + & + & -- &
\end{tabular}

RESUMO

Isolamento de vírus rábico de glândulas salivares parótidas de raposas (Pseudalopex vetulus) do Estado da Paraíba, Nordeste do Brasil.
Para determinar a presença de vírus rábico em glândulas salivares parótidas, 12 raposas (Pseudalopex vetulus) atropeladas em rodovias e positivas para raiva foram testadas pelo teste de imunofluorescência direta (IFD) e teste de inoculação em camundongos (IC). Todas as 12 
glândulas salivares parótidas foram positivas em ambos os testes, embora, em alguns casos, várias passagens terem sido necessárias. Os achados do presente trabalho reforçam a importância das raposas como reservatórios de raiva no semi-árido do Estado da Paraíba, Nordeste do Brasil.

Palavras-chave: Glândula parótida, raposa, vírus rábico, isolamento, Estado da Paraíba

\section{REFERENCES}

1. Acha, P.N.; Szyfres, B. (1986). Zoonosis y enfermedades transmisibles comunes al hombre y a los animales. 2nd ed. Organización Panamericana de la Salud, Washington, 989p.

2. Araújo, F.A.A. (2002). Raiva humana no Brasil: 1992-2001. Belo Horizonte, Brasil, 90p. (M.Sc. Dissertation, Escola de Veterinária, Universidade Federal de Minas Gerais).

3. Barros, J.S.; Freitas, C.E.A.A.; Sousa, F.S. (1989). Raiva em animais silvestres no Estado do Ceará particularmente na raposa (Dusicyon vetulus). Zoon. Rev. Int., 1, 9-13.

4. Beauregard, M.; Casey, G.A. (1965). Demonstration of rabies antigen in salivary glands of rabies suspected animals. Can. J. Comp. Med., 33, 55-58.

5. Bernardi, F.; Nadin-Davis, S.A.; Wandeler, A.I.; Armstrong, J.; Gomes A.A.B.; Lima, F.S.; Nogueira, F.R.B.; Ito, F.H. (2005). Antigenic and genetic characterization of rabies viruses isolated from domestic and wild animals of Brazil identifies the hoary fox as a rabies reservoir. J. Gen. Virol., 86, 3153-3162.

6. Carey, A.B.; Lean, R.G.M.C. (1978). Rabies antibody prevalence and virus tissue tropism in wild carnivores in Virginia. J. Wildl. Dis., 14, 487-491.

7. Carnieli Jr., P.; Brandão, P.E.; Carrieri, M.L.; Castilho, J.G.; Macedo, C.I.; Machado, L.M.; Rangel, N.; Carvalho, R.C.; Carvalho, V.A.; Montebello L.; Wada, M.; Kotait, I. (2006). Molecular epidemiology of rabies virus strains isolated from wild canids in Northeastern Brazil. Virus Res., 120, 113-120.

8. Carnieli Jr., P.; Fahl, W.O.; Castilho, J.G.; Oliveira, R.N.; Macedo, C.I.; Durymanova, E.; Jorge, R.S.P., Morato, R.G.; Spíndola, R.O.;
Machado, L.M.; Carrieri, M.L.; Kotait, I. (2008). Characterization of rabies vírus isolated from canids and identification of the main wild canid host in Northeastern Brazil. Virus Res., 131, 33-46.

9. Charlton, K.M.; Casey, G.; Webster, W.A. (1984). Rabies virus in the salivary glands and nasal mucosa of naturally infected skunks. Can. J. Comp. Med., 48, 338-339.

10. Dean, D.J.; Abelseth, M.K.; Atanasiu, P. (1996). The fluorescent antibody test. In: Meslin, F.X., Kaplan, M.M., Koprowski, H. (eds.). Laboratory techniques in rabies. 4th ed. World Health Organization, Geneva, p.88-95.

11. Delpietro, H.A.; Larghi, O.P.; Russo, R.G. (2001). Virus isolation from saliva and salivary glands of cattle naturally infected with paralytic rabies. Prev. Vet. Med., 48, 223-228.

12. Goldwasser, R.A.; Kissling, R.E. (1958). Fluorescent antibody staining of street and fixed rabies virus antigens. Proc. Soc. Exptl. Biol. Med., 98, 219-223.

13. Gomes, A.A.B. (2004). Epidemiologia da raiva: caracterização de vírus isolados de animais domésticos e silvestres do semi-árido paraibano da região de Patos, Nordeste do Brasil. São Paulo, Brasil, 107p. (Thesis, Faculdade de Medicina Veterinária e Zootecnia, Universidade de São Paulo).

14. Kobayashi, Y.; Inoue, N.; Sato, G.; Itou, T.; Santos, H. P.; Brito, C. J. C.; Gomes, A. A. B.; Santos, M. F. C.; Silva, M. V.; Mota, C. M.; Ito, F. H.; Sakai T. (2007). Phylogenetic characterization of rabies virus isolated from carnivora in Brazil. J. Vet. Med. Sci. 69, 691-696.

15. Koprowski, H. (1996). The mouse inoculation test. In: Meslin, F.X., Kaplan, M.M., Koprowski, H. (eds.) Laboratory techniques in rabies. 4th ed. World Health Organization, Geneva, p.80-87.

16. Matouch, O.; Jaros, J.; Pohl P. (1984). Excretion of the rabies virus in foxes after experimental infection. Vet. Med. (Praha), 29, 653-658.

17. Páez, A.; Saac, C.; Núñez, C.; Bóshell, J. (2005). Molecular epidemiology of rabies in northern Colombia 1994-2003. Evidence for human and fox rabies associated with dogs. Epidemiology and Infection. 133, 529-536.

18. Secord, D.C.; Bradley, J.A.; Eaton, R.D.; Mitchell, D. (1980). Prevalence of rabies virus in foxes trapped in the Canadian Artic. Can. Vet. J., 21, 297-300.

19. Sousa, M.H. (2003). Livro de registro permanente de controle da vacina anti-rábica humana. Unidade Básica de Saúde Aderban Martins, Patos, PB, Brasil, p.1-18. 